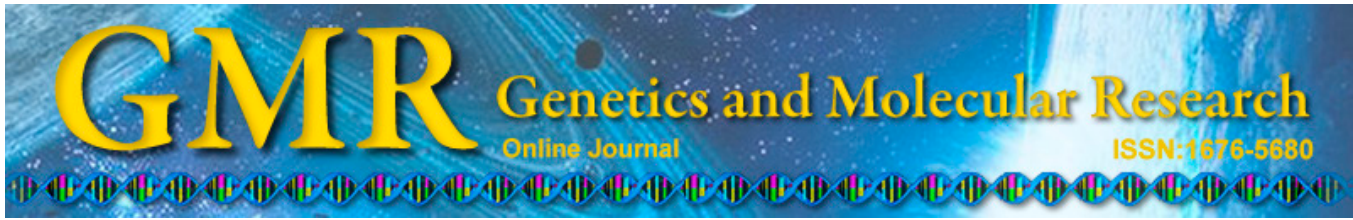

\title{
Effect of generations and environments in the analysis of a partial diallel to improve bean earliness
}

\author{
N.M. Vale, L.D. Barili, M.H. Souza, L.M.M. Moura, J.E.S. Carneiro, \\ P.C. Carneiro and F.L. Silva \\ Programa de Pós-Graduação em Genética e Melhoramento, \\ Departamento de Fitotecnia, Universidade Federal de Viçosa, \\ Viçosa, MG, Brasil \\ Corresponding author: N.M. Vale \\ E-mail: nainemartinsdovale@hotmail.com
}

Genet. Mol. Res. 14 (3): 8219-8228 (2015)

Received September 4, 2014

Accepted March 18, 2015

Published July 27, 2015

DOI http://dx.doi.org/10.4238/2015.July.27.9

\begin{abstract}
The objective of this study was to select genitors based on $F_{1}$ and $F_{2}$ generations, evaluated in different environments, to obtain segregating populations for the identification of strains showing improved earliness, yield, and carioca-type grains. Nine bean strains were crossed in a partial diallel scheme $(4 \times 5)$, in which group 1 included 4 strains with early cycles and group 2 included 5 elite strains. The $F_{1}$ and $F_{2}$ generations and the genitors were assessed in Coimbra and Viçosa in randomized blocks with 3 replications. The following characteristics were evaluated: days between sowing and emergence, and grain yield. We observed an interaction between the effects of general combining ability and specific combining ability with the environments (crop, location, and generation) for both grain earliness and yield. Genetic analysis of earliness revealed a predominance of additive effects and grain yield dominance effects. The strain Goiano Precoce may be used as a genitor in breeding programs to improve earliness, while strains RP1 and VC33 can be used to increase grain
\end{abstract}


yield. We observed genetic complementation between strains Goiano Precoce and RP1, BRSMG Madrepérola and BRS Estilo for earliness and between RP1 and Rosinha Precoce for grain yield.

Key words: Flowering; Partial diallel; Phaseolus vulgaris L.

\section{INTRODUCTION}

Over the past several years, bean breeders in Brazil have been attempted to develop early strains (Tulmann Neto and Sabino, 1994; Dalla Corte et al., 2005), with a cycle shorter than the average of 90 days of available cultivars. Early cultivars allow for cultivation at intervals of harvest as well as the sowing of other species. This increases profitability by cultivated area and number of crops per year, reduces the consumption of water and energy used for irrigation, and allows the avoidance of biotic and abiotic stresses (Buratto et al., 2007). Additionally, new bean cultivars should be productive, and emphasis has been given to carioca beans, as they are preferred by Brazilian consumers and represent approximately $79 \%$ of the Brazilian consumption of beans (Carneiro et al., 2012).

To develop bean cultivars with the desired ideotype (earliness, carioca grain, and high grain yield), hybridization methods can be used. The selection of genitors to be crossed is crucial because it determines the success of others and, consequently, the efficiency of the breeding program (Bertan et al., 2007; Pereira et al., 2007). A strategy commonly used for genitor selection is diallel crossing. This method provides information regarding the general combining ability (GCA) and specific combining ability (SCA), which are useful parameters for directing crossing to maximize performance and genetic variability in segregating populations (Bernardo and Bohn, 2007), as the alleles of interest are generally found in distinct genitors.

In bean cultivation, the use of diallel crossings is limited by the small amount of seed available in the $F_{1}$ generation because of difficulties in conducting the crossings and the limited number of hybrid seeds obtained by pollination. An alternative would be to use the $\mathrm{F}_{2}$ generation. However, in a complete diallel, considering that in each generation advanced from $\mathrm{F}_{1}$, dominance deviation is reduced to half, the effect of SCA may not be significant in subsequent generations, making it impractical because the information regarding gene complementation between the genitors would be lost (Pimentel et al., 2013). In this case, the use of a partial diallel may be more appropriate; according to Viana (2007), in partial diallel, the magnitude of GCA, in addition to quantifying the frequency of favorable alleles, indicates the genetic diversity between the genitor of a group and those of the opposite group. Furthermore, the $\mathrm{F}_{2}$ or $\mathrm{F}_{3}$ generations offer more seeds, providing the opportunity to assess the diallel in different environments, making it possible to obtain information about interaction of the parameters estimated in the diallel with environmental effects (Bhullar et al., 1979; Masood and Kronstad, 2000). Thus, these generations allow for a more efficient choice of genitors to obtain promising segregating populations to identify superior strains of bean crop, particularly those that are better adapted to a wider range of environmental conditions.

The aim of this study was to select genitors using $F_{1}$ and $F_{2}$ generations evaluated in more than one environment to obtain promising segregating populations and identify superior strains for traits of earliness, yield, and standard of carioca-type grain. 


\section{MATERIAL AND METHODS}

Nine bean strains were crossed in a partial diallel scheme (4 x 5); group I consisted of 4 strains (Goiano Precoce; Xan112; Carioca1070; Rosinha Precoce) with an early cycle and group II consisted of 5 elite strains, with a normal cycle, high yield potential, and cariocatype grain (RP1, VC15, VC33, BRSMG Madrepérola, and BRS Estilo). The $\mathrm{F}_{1}$ hybrids and the genitors were assessed from the crop of the 2013 drought at the Experimental Station of Coimbra, MG (690 m altitude, $20^{\circ} 45^{\prime} \mathrm{S}$ latitude and $42^{\circ} 51^{\prime} \mathrm{W}$ longitude) and at the Experimental Station of Horta Nova, in Viçosa, MG (648 m altitude, $20^{\circ} 45^{\prime} 14^{\prime \prime}$ S latitude and $42^{\circ} 52^{\prime}$ $\mathrm{W} 55^{\prime \prime} \mathrm{W}$ longitude). The experimental design was a randomized block with 3 replications. The parcels consisted of 2 lines $1.0 \mathrm{~m}$ in length with spacing of $0.50 \mathrm{~m}$ and 10 seeds $/ \mathrm{m}$. In 2013, we evaluated the $\mathrm{F}_{2}$ generation of each hybrid along with the genitors in the winter crop in Coimbra and water crop in Viçosa. A randomized block design with 3 replications was also used, but with parcels of 4 lines of $4.0 \mathrm{~m}$ in length and spacing of $0.50 \mathrm{~m}$.

Fertilization and crop pest controls were performed according to the recommendations for cultivation in the region. Cycle and grain yield in $\mathrm{kg} / \mathrm{ha}$ (YLD) were evaluated. Plant cycle evaluation was based on the number of days between sowing and emergence (DSE) ( $50 \%$ of plants in the parcels with at least 1 open flower).

Data were subjected to individual and combined analysis of variance and the effect of treatments was decomposed according to the Griffing model (1956), adapted to partial diallel by Geraldi and Miranda-Filho (1988). The effect of treatments was considered as fixed and the effect of environments was considered as random. The model used was:

$$
Y_{i j}=\mu+\frac{1}{2}\left(d_{1}+d_{2}\right)+g_{i}+g_{j}^{\prime}+s_{i j}+\bar{\varepsilon}_{i j}
$$

where $Y_{i j}$ is the mean of the crossing involving the $\mathrm{i}^{\text {th }}$ genitor of group I and the $\mathrm{j}^{\text {th }}$ genitor of group II; $Y_{i 0}$ is the average of the $i t h$ genitor of group I $(\mathrm{i}=0,1, \ldots \mathrm{p}) ; Y_{0 j}$ is the mean of the $\mathrm{j}^{\text {th }}$ genitor of group II $(\mathrm{j}=0,1, \ldots \mathrm{q}) ; \mu$ is the general mean of diallel; $d_{1}, d_{2}$ are the contrasts involving the means of groups I and II and the general average; $g_{i}$ is the effect of general combining ability of the $\mathrm{i}^{\text {th }}$ genitor of group I; $g_{j}$ is the effect of GCA of the $\mathrm{j}^{\text {th }}$ genitor of group II; $s_{i j}$ is the effect of SCA; and $\bar{\varepsilon}_{i j}$ is the experimental mean error.

Statistical analyses were performed using the GENES program (Cruz, 2013).

\section{RESULTS AND DISCUSSION}

Summaries of the individual (Coimbra and Viçosa) and combined analyses of variance of the partial diallel for the number of DSE and YLD evaluated in the 9 genitors and their $20 \mathrm{~F}_{1}$ hybrids are presented in Table 1 . The 9 genitors and $\mathrm{F}_{2}$ generations are presented in Table 2. The effect of treatments on individual analysis was significant in both generations (Tables 1 and 2), which was observed in GCA in groups I (GCA I) and II (GCA II) and SCA for the $\mathrm{F}_{1}$ and $\mathrm{F}_{2}$ generations.

The square sums of GCAs of the genitors (GCA I + GCA II), compared to the square sum of the SCA of the hybrids (Table 1) showed a predominance of additive effects in Coimbra and dominance in Viçosa for DSE. In the $\mathrm{F}_{2}$ generation (Table 2), there was predominance of additive effects in both Coimbra and Viçosa. For grain yield, there was a predominance of dominance effects in the genetic control in both environments for the $\mathrm{F}_{1}$ generation (Co- 
imbra and Viçosa) (Table 1). In $\mathrm{F}_{2}$, there was a predominance of additive effects in Coimbra and dominance in Viçosa. These results revealed a greater effect of dominance effects on the genetic control of YLD regarding DSE, as the dominance deviations decreased by half with each generation by self-fertilization. Moreover, over generations, an increase in the frequency of homozygous loci was expected, as well as an increase in the participation of additive variance at the expense of dominance variance. Characters such as grain yield are controlled by a large number of genes (Ribeiro et al., 2008) and require a higher degree of homozygosity to reduce the effects of dominance. Thus, selections aiming to improve the earliness trait can be manipulated in initial generations because of the predominance of additive effects for DSE in $\mathrm{F}_{2}$, while selections aiming to improve YLD should be manipulated in advanced generations.

\begin{tabular}{|c|c|c|c|c|c|}
\hline \multirow[t]{3}{*}{ Individual variance } & \multirow[t]{3}{*}{ d.f. } & \multicolumn{4}{|c|}{ Mean square } \\
\hline & & \multicolumn{2}{|c|}{ Coimbra } & \multicolumn{2}{|c|}{ Viçosa } \\
\hline & & DSE & YLD & DSE & YLD \\
\hline Treatments & 28 & $46.27 * *$ & $943408 * *$ & $146.68^{* *}$ & 745751 ** \\
\hline Groups & 1 & $484.94 * *$ & $6529532 * *$ & $468.39^{* *}$ & $139089^{\text {ns }}$ \\
\hline GCA I & 3 & $169.11^{* *}$ & $1590122^{* *}$ & $132.75 * *$ & $892643 *$ \\
\hline GCA II & 4 & $6.45^{\text {ns }}$ & $377695^{*}$ & $127.87^{* *}$ & $944356^{*}$ \\
\hline $\mathrm{SCA}$ & 20 & $13.87^{* *}$ & $680237 * *$ & $136.44 * *$ & $714330^{* * *}$ \\
\hline Residues & 56 & 5.16 & 144247 & 7.00 & 302604 \\
\hline Mean & - & 37.36 & 2336 & 40.52 & 2187 \\
\hline CV (\%) & - & 6 & 16 & 9 & 25 \\
\hline \multirow[t]{2}{*}{ Combined variance } & \multirow[t]{2}{*}{ d.f. } & \multicolumn{4}{|c|}{ Mean square } \\
\hline & & DSE & & YLD & \\
\hline Treatments (Treat) & 28 & $97.85^{\text {ns }}$ & & $818280^{\text {ns }}$ & \\
\hline Groups & 1 & $07.00^{\text {ns }}$ & & $2381321 *$ & \\
\hline GCA I & 3 & $283.48^{*}$ & & $1343529^{\text {ns }}$ & \\
\hline GCA II & 4 & $49.81^{\text {ns }}$ & & $570338^{\text {ns }}$ & \\
\hline SCA & 20 & $84.50^{\text {ns }}$ & & $710929^{\text {ns }}$ & \\
\hline Environments (Env) & 1 & $0.31^{\mathrm{ns}}$ & & $526^{\mathrm{ns}}$ & \\
\hline Treat $x$ Env & 28 & $95.10^{* *}$ & & $870879 * *$ & \\
\hline Groups x Env & 2 & $476.63 * *$ & & $2143649 * *$ & \\
\hline GCA I x Env & 3 & $18.37 * *$ & & $1139236^{* * *}$ & \\
\hline GCA II x Env & 4 & $84.50^{*}$ & & $751713^{* *}$ & \\
\hline SCA x Env & 20 & $82.70^{* * *}$ & & $683638^{* *}$ & \\
\hline Residues & 112 & 6.00 & & 223425 & \\
\hline Mean & - & 38.94 & & 2261 & \\
\hline CV (\%) & - & 8 & & 20 & \\
\hline
\end{tabular}

d.f. = degrees of freedom; GCA = general combining ability; SCA = specific combining ability; $\mathrm{CV}=$ coefficient of variance. ${ }^{\mathrm{ns}, *, * * N o t}$ significant, significant at $5 \%$ and significant at $1 \%$ probability, respectively, by the $\mathrm{F}$-test.

The effect of the environment was not significant in $\mathrm{F}_{1}$ (Table 1) and $\mathrm{F}_{2}$ (Table 2) in the combined analysis, but all interactions with the environments were significant in both generations except the group $\mathrm{x}$ environment interaction and GCA I $\mathrm{x}$ environments in $\mathrm{F}_{2}$ (Table 2) for grain yield. Pixley and Bjarnason (1993) reported an interaction between GCA and SCA parameters with environment effects for grain yield and disease resistance in maize.

Based on estimated GCA of the genitors in (GCA I for DSE, the Goiano Precoce strain stood out with negative and significant values in both evaluated generations, $F_{1}$ (Table 3 ) and $\mathrm{F}_{2}$ (Table 4), and in both locations (Coimbra and Viçosa). Negative values are informative 
because the earliest plants present lower DSE. These results indicate a high concentration of favorable alleles in this strain for the reduction of the bean cycle.

\begin{tabular}{|c|c|c|c|c|c|}
\hline \multirow[t]{3}{*}{ Individual variance } & \multirow[t]{3}{*}{ d.f. } & \multicolumn{4}{|c|}{ Mean square } \\
\hline & & \multicolumn{2}{|c|}{ Coimbra-winter } & \multicolumn{2}{|c|}{ Viçosa-water } \\
\hline & & DSE & YLD & DSE & YLD \\
\hline Treatments & 28 & $44.03^{* *}$ & $417682 * *$ & $29.64 * *$ & $780827^{* * *}$ \\
\hline Groups & 1 & $423.74 * *$ & $2292099 * *$ & $1.20^{\mathrm{ns}}$ & $1173009^{* *}$ \\
\hline GCA I & 3 & $191.33^{* *}$ & $1152108 * *$ & $81.19^{* *}$ & 769771 ** \\
\hline GCA II & 4 & $27.48^{*}$ & $608577 * *$ & $32.81 * *$ & $1112880^{* *}$ \\
\hline SCA & 20 & $6.2^{\text {ns }}$ & $175619^{\text {ns }}$ & $22.70 * *$ & $696466^{* *}$ \\
\hline Residues & 56 & 9.43 & 146567 & 5.12 & 179956 \\
\hline Mean & - & 44 & 3306 & 37 & 2365 \\
\hline $\mathrm{CV}(\%)$ & - & 6 & 11 & 6 & 18 \\
\hline \multirow[t]{2}{*}{ Combined variance } & d.f. & \multicolumn{4}{|c|}{ Mean square } \\
\hline & & \multicolumn{2}{|c|}{ DSE } & \multicolumn{2}{|c|}{ YLD } \\
\hline Treatments (Treat) & 28 & \multicolumn{2}{|c|}{$48.60^{*}$} & \multicolumn{2}{|c|}{$745296^{\mathrm{ns}}$} \\
\hline Groups & 1 & \multicolumn{2}{|c|}{$235.06^{* *}$} & \multicolumn{2}{|c|}{3372266 ** } \\
\hline GCA I & 3 & \multicolumn{2}{|c|}{$221.70^{\text {ns }}$} & \multicolumn{2}{|c|}{$1718332^{\text {ns }}$} \\
\hline GCA II & 4 & \multicolumn{2}{|c|}{$34.93^{\text {ns }}$} & \multicolumn{2}{|c|}{$921658^{\mathrm{ns}}$} \\
\hline $\mathrm{SCA}$ & 12 & \multirow{2}{*}{\multicolumn{2}{|c|}{$\begin{array}{r}16.04^{\text {ns }} \\
6.61^{\text {ns }}\end{array}$}} & \multicolumn{2}{|c|}{$432720^{\text {ns }}$} \\
\hline Environments (Env) & 1 & & & \\
\hline Treat $x$ Env & 28 & \multicolumn{2}{|c|}{$2508 * *$} & \multirow{2}{*}{\multicolumn{2}{|c|}{$453214 * *$}} \\
\hline Groups x Env & 2 & \multicolumn{2}{|c|}{$94.94 * *$} & & $4642^{\text {ns }}$ \\
\hline GCA I x Env & 3 & \multicolumn{2}{|c|}{$50.81 * *$} & \multirow{2}{*}{\multicolumn{2}{|c|}{$\begin{array}{l}203547^{\text {ns }} \\
799799^{* *}\end{array}$}} \\
\hline GCA II x Env & 4 & \multicolumn{2}{|c|}{$25.36^{* *}$} & & \\
\hline SCA x Env & 12 & \multicolumn{2}{|c|}{$12.92 * *$} & \multicolumn{2}{|c|}{$439365 * *$} \\
\hline Residues & 112 & \multicolumn{2}{|c|}{7.27} & \multicolumn{2}{|c|}{163261} \\
\hline Mean & - & \multicolumn{2}{|c|}{41} & \multicolumn{2}{|c|}{163262} \\
\hline CV (\%) & - & & & & \\
\hline
\end{tabular}

ns, *,**Not significant, significant at $5 \%$ and significant at $1 \%$ probability, respectively, by the F-test. For abbreviations, see Table1.

Table 3. Estimates of the effects of general combining ability (GCA) of 9 bean strains and specific combining ability (SCA) of their $20 \mathrm{~F}_{1}$ hybrids evaluated as for days between sowing and emergence in Coimbra and Viçosa, MG. Drought of 2013.

\begin{tabular}{|c|c|c|c|c|c|c|}
\hline \multicolumn{7}{|c|}{ Coimbra-drought } \\
\hline Genitors & 1 & 2 & 3 & 4 & 5 & GCA I \\
\hline $1 *$ & $-5.06^{\mathrm{A} * *}$ & $1.30^{\mathrm{ns}}$ & $-0.06^{\text {ns }}$ & $1.18^{\mathrm{ns}}$ & $0.06^{\mathrm{ns}}$ & $-3.44 *$ \\
\hline $2 *$ & $0.93^{\mathrm{ns}}$ & $-0.69^{\text {ns }}$ & $-1.06^{\mathrm{ns}}$ & $-3.81 * *$ & $0.06^{\mathrm{ns}}$ & $2.5^{*}$ \\
\hline $3 *$ & $1.04^{\mathrm{ns}}$ & $1.42^{\mathrm{ns}}$ & $-0.95^{\mathrm{ns}}$ & $-0.70^{\mathrm{ns}}$ & $2.04^{\mathrm{ns}}$ & $0.44^{\mathrm{ns}}$ \\
\hline $4 *$ & $2.04^{\mathrm{ns}}$ & $-0.57^{\mathrm{ns}}$ & $3.04 *$ & $-0.70^{\mathrm{ns}}$ & $1.04^{\mathrm{ns}}$ & $0.45^{\mathrm{ns}}$ \\
\hline GCA II & $-0.27^{\mathrm{ns}}$ & $0.35^{\mathrm{ns}}$ & $-0.27^{\mathrm{ns}}$ & $-0.52^{\mathrm{ns}}$ & $0.71^{\mathrm{ns}}$ & \\
\hline \multicolumn{7}{|c|}{ Viçosa-drought } \\
\hline Genitors & 1 & 2 & 3 & 4 & 5 & GCA I \\
\hline $1 *$ & $3.58^{\mathrm{ns}}$ & $3.45^{\mathrm{ns}}$ & $-2.04^{\text {ns }}$ & $0.20^{\mathrm{ns}}$ & $5.70 * *$ & $-3.13 * *$ \\
\hline $2 *$ & $4.24 *$ & $4.12^{\mathrm{ns}}$ & $-2.37^{\mathrm{ns}}$ & $-1.12^{\mathrm{ns}}$ & $3.37^{\mathrm{ns}}$ & $1.19^{\mathrm{ns}}$ \\
\hline $3 *$ & $7.58 * *$ & $10.45 * *$ & $1.95^{\mathrm{ns}}$ & $-2.70^{\mathrm{ns}}$ & $1.70^{\text {ns }}$ & $1.86^{*}$ \\
\hline $4 *$ & $3.35^{\mathrm{ns}}$ & $3.23^{\mathrm{ns}}$ & $-2.26^{\mathrm{ns}}$ & $-2.01^{\mathrm{ns}}$ & $9.48 * *$ & $0.08^{\mathrm{ns}}$ \\
\hline GCA II & $-2.00 * *$ & $-1.87 * *$ & $2.62 *$ & $2.37 *$ & $-1.12^{\mathrm{ns}}$ & \\
\hline
\end{tabular}

Genitors of group 1: 1* - Goiano Precoce; 2* - Xan112; 3* - Carioca 1070; 4* - Rosinha Precoce. Genitors of group 2: 1 - RP1; 2 - VC15; 3 - VC33; 4 - BRSMG Madrepérola; 5 - BRS Estilo. ${ }^{A}$ SCA value. ${ }^{\text {ns, } *, * * N o t ~ s i g n i f i c a n t, ~}$ significant at $5 \%$ and significant at $1 \%$ probability, respectively, by the $t$-test. 
Table 4. Estimates of the effects of general combining ability (GCA) of 9 bean strains and specific combining ability (SCA) of their $20 \mathrm{~F}_{2}$ populations evaluated for number of days between sowing and emergence, Coimbra and Viçosa, MG, 2013.

\begin{tabular}{|c|c|c|c|c|c|c|}
\hline \multirow[b]{2}{*}{ Genitors } & \multicolumn{6}{|c|}{ Coimbra-winter } \\
\hline & 1 & 2 & 3 & 4 & 5 & GCA I \\
\hline $1^{*}$ & $0.43^{\text {Ans }}$ & $-2.68^{\mathrm{ns}}$ & $-0.68^{\mathrm{ns}}$ & $-0.18^{\mathrm{ns}}$ & $0.18^{\mathrm{ns}}$ & $-3.88^{*}$ \\
\hline $2^{*}$ & $-0.56^{\mathrm{ns}}$ & $0.31^{\mathrm{ns}}$ & $-0.68^{\mathrm{ns}}$ & $-1.18^{\mathrm{ns}}$ & $-2.81^{\mathrm{ns}}$ & $2.11 *$ \\
\hline $3^{*}$ & $0.88^{\mathrm{ns}}$ & $-0.24^{\mathrm{ns}}$ & $-1.24^{\mathrm{ns}}$ & $-1.74^{\mathrm{ns}}$ & $1.63^{\mathrm{ns}}$ & $0.66^{\mathrm{ns}}$ \\
\hline $4^{*}$ & $0.43^{\mathrm{ns}}$ & $0.31^{\text {ns }}$ & $3.11^{\mathrm{ns}}$ & $0.81^{\mathrm{ns}}$ & $-0.81^{\mathrm{ns}}$ & $1.11^{\mathrm{ns}}$ \\
\hline \multirow[t]{2}{*}{ GCA II } & $1.17^{\mathrm{ns}}$ & $0.30^{\text {ns }}$ & $-1.69^{*}$ & -0.2 & 0.42 & \\
\hline & \multicolumn{6}{|c|}{ Viçosa-water } \\
\hline Genitors & 1 & 2 & 3 & 4 & 5 & GCA I \\
\hline$\overline{1 *}$ & $0.88^{\mathrm{ns}}$ & $0.73^{\mathrm{ns}}$ & $0.39^{\text {ns }}$ & $-6.73 *$ & $-3.48^{*}$ & $-1.36^{* *}$ \\
\hline $2^{*}$ & $-3.9^{*}$ & $2.37^{\mathrm{ns}}$ & $1.50^{\mathrm{ns}}$ & $0.37^{\mathrm{ns}}$ & $1.62^{\mathrm{ns}}$ & $2.52 *$ \\
\hline $3 *$ & $1.89^{\text {ns }}$ & $-1.73^{\mathrm{ns}}$ & $0.39^{\text {ns }}$ & $-0.73^{\mathrm{ns}}$ & $0.51^{\mathrm{ns}}$ & $-0.36^{\mathrm{ns}}$ \\
\hline $4 *$ & $-0.66^{\text {ns }}$ & $-3.29^{\mathrm{ns}}$ & $1.83^{\text {ns }}$ & $1.70^{\mathrm{ns}}$ & $0.95^{\mathrm{ns}}$ & $-0.80^{\mathrm{ns}}$ \\
\hline GCA II & $1.37^{*}$ & $-1.0^{\mathrm{ns}}$ & $-0.12^{\mathrm{ns}}$ & $1.0^{\mathrm{ns}}$ & $-1.25^{* *}$ & \\
\hline
\end{tabular}

Genitors of group 1: 1* - Goiano Precoce; 2* - Xan112; 3* - Carioca1070; 4* - Rosinha Precoce. Genitors of group

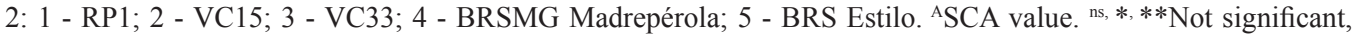
significant at $5 \%$ and significant at $1 \%$ probability, respectively, by the $t$-test.

For group II, based on the estimates of GCA (GCA II), the RP1 and VC15 strains in Viçosa stood out for the DSE in the $\mathrm{F}_{1}$ generation (Table 3) and VC33 (in Coimbra) and BRS Estilo (in Viçosa) in the generation $\mathrm{F}_{2}$ (Table 4). These results corroborate the influence of the environments (crops and location) on the estimates of GCA. Notably, the effect of environments can be mistaken for the one of the generations.

Based on the estimates for SCA, the hybrid combination Goiano Precoce/RP1 stood out in the reduction of DSE in Coimbra in the crop of the 2013 drought for the $\mathrm{F}_{1}$ generation (Table 3). In Viçosa, in the same crop and generation, no hybrid combination stood out because all combinations with the Goiano Precoce strain showed no significant SCA. These results indicate that gene complementation occurred between the genitors Goiano Precoce and RP1 for the reduction of the cycle only in Coimbra, which also indicates the relationship between location and cycle.

Based on the estimates for SCA in the $\mathrm{F}_{2}$ generation (Table 4) the hybrid combinations Goiano Precoce/BRSMG Madrepérola and Goiano Precoce/BRS Estilo stood out, presenting negative and significant estimates of SCA in Viçosa for the water crop of 2013. SCA was not significant in the same generation for the winter crop of Coimbra. These results indicate the effects of the interaction between SCA and the environment, and in this case, includes the effect of crops.

There are no published reports of studies using partial diallel in beans to analyze more than one generation from the number of days to begin flowering and cycle. Javaid et al. (2001) examined the efficiency of the $\mathrm{F}_{2}$ generation of wheat to estimate GCA and SCA for cycle, yield per plant, and thousand grain weight.

Considering the estimates of GCA (GCA I) for YLD in the $\mathrm{F}_{1}$ generation, the strain Rosinha Precoce showed positive and significant values in Viçosa, while in Coimbra, no strain showed positive and significant values (Table 5). Based on the $F_{2}$ generation (Table 6), the strain Xan112 showed positive and significant values in Coimbra and Carioca1070 in Viçosa. These results confirm the effects of the interaction with the environment when estimating GCA. The interaction between genotypes and environments in bean cultivation for grain yield has been reported by several authors (Carmo et al., 2007; Bertoldo et al., 2009; Coimbra et al., 2009). 
Table 5. Estimates of the effects of general combining ability (GCA) of 9 bean strains and specific combining ability (SCA) of their $20 \mathrm{~F}_{1}$ hybrids evaluated for grain yield in $\mathrm{kg} / \mathrm{ha}$, in Coimbra and Viçosa, MG. Drought of 2013.

\begin{tabular}{|c|c|c|c|c|c|c|}
\hline \multicolumn{7}{|c|}{ Coimbra-drought } \\
\hline Genitors & 1 & 2 & 3 & 4 & 5 & GCA I \\
\hline $1 *$ & $-1222^{\mathrm{A} * *}$ & $394^{\mathrm{ns}}$ & $254^{\mathrm{ns}}$ & $588 * *$ & $85^{\mathrm{ns}}$ & $-358 *$ \\
\hline $2 *$ & $240^{\mathrm{ns}}$ & $98^{\text {ns }}$ & $-192^{\text {ns }}$ & $119^{\text {ns }}$ & $183^{\text {ns }}$ & $168^{\mathrm{ns}}$ \\
\hline $3 *$ & $108^{\text {ns }}$ & $197^{\mathrm{ns}}$ & $195^{\mathrm{ns}}$ & $-173^{\mathrm{ns}}$ & $316^{\text {ns }}$ & $125^{\mathrm{ns}}$ \\
\hline $4^{*}$ & $696^{* *}$ & $212^{\mathrm{ns}}$ & $498 * *$ & $-100^{\mathrm{ns}}$ & $189^{\text {ns }}$ & $65^{\mathrm{ns}}$ \\
\hline GCA II & $115^{*}$ & $85^{\mathrm{ns}}$ & $-55^{\mathrm{ns}}$ & $-190^{*}$ & $45^{\text {ns }}$ & \\
\hline \multicolumn{7}{|c|}{ Viçosa-drought } \\
\hline Genitors & 1 & 2 & 3 & 4 & 5 & GCA I \\
\hline $1 *$ & $16^{\mathrm{ns}}$ & $-516^{\mathrm{ns}}$ & $-881 * *$ & $339^{\mathrm{ns}}$ & $126^{\mathrm{ns}}$ & $-68^{\mathrm{ns}}$ \\
\hline $2 *$ & $20^{\text {ns }}$ & $-181^{\mathrm{ns}}$ & $-117^{\text {ns }}$ & $195^{\mathrm{ns}}$ & $-95^{\mathrm{ns}}$ & $-121^{\mathrm{ns}}$ \\
\hline $3 *$ & $-239^{\text {ns }}$ & $-681 *$ & $397^{\mathrm{ns}}$ & $133^{\mathrm{ns}}$ & $-284^{\mathrm{ns}}$ & $-81^{\mathrm{ns}}$ \\
\hline $4 *$ & $432^{\mathrm{ns}}$ & $-439^{\text {ns }}$ & $884 * *$ & $-23^{\mathrm{ns}}$ & $39^{\text {ns }}$ & $270^{*}$ \\
\hline GCA II & $260 *$ & $-254^{*}$ & $47^{\mathrm{ns}}$ & $74^{\text {ns }}$ & $-127^{\mathrm{ns}}$ & \\
\hline
\end{tabular}

Genitors of group 1: 1* - Goiano Precoce; 2* - Xan112;3* - Carioca 1070; 4* - Rosinha Precoce. Genitors of group

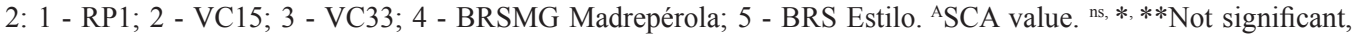
significant at $5 \%$ and significant at $1 \%$ probability, respectively, by the $t$-test.

Table 6. Estimates of the effects of general combining ability (GCA) of 9 bean strains and specific combining ability (SCA) of their $20 \mathrm{~F}_{2}$ populations evaluated for grain yield in $\mathrm{kg} / \mathrm{ha}$, in Coimbra and Viçosa, MG, 2013.

\begin{tabular}{|c|c|c|c|c|c|c|}
\hline \multicolumn{7}{|c|}{ Coimbra-winter } \\
\hline Genitors & 1 & 2 & 3 & 4 & 5 & $\overline{\text { GCA I }}$ \\
\hline $1 *$ & $-171^{\text {Ans }}$ & $-331^{\mathrm{ns}}$ & $-195^{\mathrm{ns}}$ & $-24^{\mathrm{ns}}$ & $-46^{\mathrm{ns}}$ & $-302 *$ \\
\hline $2 *$ & $-108^{\mathrm{ns}}$ & $332^{\text {ns }}$ & $24^{\mathrm{ns}}$ & $88^{\mathrm{ns}}$ & $121^{\mathrm{ns}}$ & $156^{*}$ \\
\hline $3 *$ & $-53^{\mathrm{ns}}$ & $167^{\mathrm{ns}}$ & $-204^{\mathrm{ns}}$ & $313^{\mathrm{ns}}$ & $177^{\mathrm{ns}}$ & $89^{\mathrm{ns}}$ \\
\hline $4 *$ & $25^{\mathrm{ns}}$ & $283^{\mathrm{ns}}$ & $93^{\mathrm{ns}}$ & $-409^{\mathrm{ns}}$ & $-196^{\mathrm{ns}}$ & $57^{\mathrm{ns}}$ \\
\hline GCA II & $182 *$ & $-22^{\mathrm{ns}}$ & $-11^{\mathrm{ns}}$ & $94^{\mathrm{ns}}$ & $-243^{*}$ & \\
\hline \multicolumn{7}{|c|}{ Viçosa-waters } \\
\hline Genitors & 1 & 2 & 3 & 4 & 5 & GCA I \\
\hline $1 *$ & $-80^{\mathrm{ns}}$ & $-468^{*}$ & $218^{\mathrm{ns}}$ & $-243^{\mathrm{ns}}$ & $227^{\mathrm{ns}}$ & $-220 *$ \\
\hline $2 *$ & $276^{\mathrm{ns}}$ & $-248^{\mathrm{ns}}$ & $196^{\mathrm{ns}}$ & $337^{\mathrm{ns}}$ & $576^{* *}$ & $-15^{\mathrm{ns}}$ \\
\hline $3 *$ & $563^{* *}$ & $-497^{*}$ & $-10^{\mathrm{ns}}$ & $-596 * *$ & $551 * *$ & $183^{*}$ \\
\hline $4 *$ & $-454 *$ & $-162^{\mathrm{ns}}$ & $22^{\mathrm{ns}}$ & $-347^{\mathrm{ns}}$ & $340^{\mathrm{ns}}$ & $52^{\mathrm{ns}}$ \\
\hline GCA II & $102^{\mathrm{ns}}$ & $-316^{* *}$ & $262 *$ & $-71^{\mathrm{ns}}$ & $23^{\mathrm{ns}}$ & \\
\hline
\end{tabular}

Genitors of group 1: 1* - Goiano Precoce-; 2* - Xan112;3* - Carioca 1070; 4* - Rosinha Precoce. Genitors of group

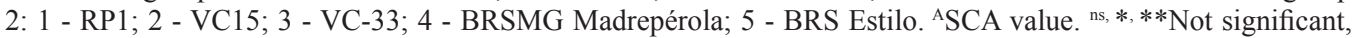
significant at $5 \%$ and significant at $1 \%$ probability, respectively, by the $t$-test.

Based on the estimates of GCA for the genitors in group II (GCA II) to YLD in the $\mathrm{F}_{1}$ generation (Table 5) and in the $\mathrm{F}_{2}$ generation (Table 6), the RP1 strain stood out. Only in the $\mathrm{F}_{2}$ generation in Viçosa, this strain showed no significant effect of GCA in the water crop of 2013 (Table 6). In this crop, the VC33 strain showed positive and significant estimates of GCA.

In $\mathrm{F}_{1}$ generation (crop of the 2013 drought in Coimbra), only the combination Rosinha Precoce/RP1 showed a positive and significant effect of SCA for YLD (Table 5). In Viçosa, for this same crop and generation, no hybrid combination stood out because all combinations with the RP1 strain showed no significant estimates for SCA. These results indicate gene complementation between RP1 and Rosinha Precoce genitors for the increase in grain yield as well as 
an interaction between the location and grain yield, as the $F_{1}$ generation was evaluated in the same crop but in different locations.

In the $\mathrm{F}_{2}$ generation, the SCA for YLD was not significant in Coimbra in the winter crop of 2013 (Table 6). Although the SCA to YLD was significant in Viçosa in the water crop in 2013, no population showed a significant effect of SCA when the VC33 strain was crossed; the VC33 strain stood out in this crop and generation for the estimate of GCA.

The 3 hybrid combinations of Goiano Precoce/RP1, Goiano Precoce/BRS Madrepérola, and Goiano Precoce/BRS Estilo are the most promising for obtaining early strains and share the Goiano Precoce strain as the common genitor. Only in Viçosa in the $\mathrm{F}_{2}$ generation, the combinations Goiano Precoce/BRSMG Madrepérola and Goiano Precoce/BRS Estilo flowered at 30 and 31 days, respectively, and exceeded the Goiano Precoce strain that flourished at 32 days (Table 7). The cultivar IPR Andorinha, which is considered as early and was launched in 2012, shows an average flowering time of 35 days (Külzer, 2012).

Table 7. Average of 9 strains, their $20 \mathrm{~F}_{1}$ hybrids and $20 \mathrm{~F}_{2}$ populations for the number of days between sowing and emergence (DSE) and grain yield (YLD) in kg/ha, in Coimbra and Viçosa, MG, 2013.

\begin{tabular}{|c|c|c|c|c|c|c|c|c|c|}
\hline & \multirow[t]{3}{*}{ Treatment } & \multicolumn{4}{|c|}{$\mathrm{F}_{1}$} & \multicolumn{4}{|c|}{$\mathrm{F}_{2}$} \\
\hline & & \multicolumn{2}{|c|}{ Coimbra } & \multicolumn{2}{|c|}{ Viçosa } & \multicolumn{2}{|c|}{ Coimbra } & \multicolumn{2}{|c|}{ Viçosa } \\
\hline & & DSE & YLD & DSE & YLD & DSE & YLD & DSE & YLD \\
\hline \multirow[t]{4}{*}{ Group I } & 1- Goiano precoce & 27 & 1949 & 30 & 2521 & 34 & 2782 & 32 & 1881 \\
\hline & 2- Xan112 & 37 & 1827 & 40 & 2046 & 47 & 3088 & 41 & 1549 \\
\hline & 3- Carioca 1070 & 32 & 1645 & 34 & 2324 & 42 & 2984 & 36 & 2511 \\
\hline & 4- Rosinha Precoce & 31 & 1797 & 35 & 2294 & 42 & 3222 & 35 & 2457 \\
\hline \multirow[t]{5}{*}{ Group II } & 1'- RP1 & 39 & 3021 & 41 & 2462 & 50 & 4107 & 41 & 2619 \\
\hline & 2'- VC15 & 36 & 2421 & 39 & 2455 & 50 & 3318 & 37 & 2622 \\
\hline & $3^{\prime}-\mathrm{VC} 33$ & 40 & 2203 & 43 & 2009 & 46 & 3707 & 35 & 2779 \\
\hline & 4'- BRSMG Madrepérola & 42 & 2104 & 42 & 1833 & 49 & 3792 & 42 & 2849 \\
\hline & 5'- BRS Estilo & 37 & 2412 & 39 & 1906 & 50 & 3076 & 35 & 1767 \\
\hline \multirow[t]{20}{*}{ Hybrid combinations } & $1 / 1$ & 29 & 2232 & 33 & 2337 & 42 & 3004 & 38 & 2159 \\
\hline & $1, / 2$ & 40 & 2733 & 43 & 2288 & 47 & 3527 & 37 & 2722 \\
\hline & $1^{\prime} / 3$ & 38 & 2558 & 43 & 2067 & 47 & 3515 & 40 & 3208 \\
\hline & $1 \% / 4$ & 39 & 3085 & 41 & 3091 & 47 & 3562 & 37 & 2059 \\
\hline & $2 \% / 1$ & 35 & 2330 & 38 & 1888 & 38 & 2639 & 34 & 1352 \\
\hline & $2 ' / 2$ & 39 & 2561 & 43 & 2570 & 47 & 3763 & 41 & 1778 \\
\hline & $2^{\prime} / 3$ & 38 & 2618 & 44 & 2009 & 45 & 3531 & 34 & 1728 \\
\hline & $2 \% / 4$ & 37 & 2572 & 41 & 2003 & 46 & 3616 & 32 & 1933 \\
\hline & $3 \% / 1$ & 33 & 2045 & 37 & 1924 & 38 & 2786 & 36 & 2619 \\
\hline & $3^{\prime} / 2$ & 38 & 2124 & 41 & 1936 & 44 & 3466 & 41 & 2802 \\
\hline & $3^{\prime} / 3$ & 36 & 2470 & 36 & 2491 & 42 & 3170 & 37 & 2794 \\
\hline & $3^{\prime} / 4$ & 40 & 2712 & 40 & 3330 & 44 & 3436 & 38 & 2897 \\
\hline & $4^{\prime} / 1$ & 34 & 2248 & 39 & 2473 & 40 & 3063 & 30 & 1822 \\
\hline & $4^{\prime} / 2$ & 35 & 2306 & 42 & 2276 & 45 & 3636 & 41 & 2608 \\
\hline & $4^{\prime} / 3$ & 36 & 1970 & 41 & 2354 & 43 & 3794 & 37 & 1873 \\
\hline & $4^{\prime} / 4$ & 36 & 1982 & 42 & 2449 & 46 & 3039 & 39 & 1992 \\
\hline & $5 \% / 1$ & 34 & 1985 & 39 & 2057 & 41 & 2704 & 31 & 2389 \\
\hline & $5, / 2$ & 40 & 2609 & 43 & 2182 & 44 & 3332 & 40 & 2943 \\
\hline & $5, / 3$ & 40 & 2700 & 42 & 1933 & 47 & 3321 & 36 & 3117 \\
\hline & $5 \% / 4$ & 39 & 2512 & 41 & 2309 & 45 & 2916 & 36 & 2776 \\
\hline
\end{tabular}

The hybrid combination Rosinha Precoce/RP1 was the most promising for production potential, surpassing the genitor with higher yield in the $\mathrm{F}_{1}$ generation, strain RP1 (Table 7), indicating that the SCA effects were significant both in Viçosa and Coimbra (Table 5). In the $\mathrm{F}_{2}$, this combination did not exceed the average of their genitors in Coimbra and showed 398 $\mathrm{kg} /$ ha lower yield than their genitor with the lower yield average (Rosinha Precoce) (Table 7). 
These results indicate the presence of dominance deviations in the control of grain yield and an interaction between SCA effects and environment for this characteristic (Table 6).

We observed an interaction between the effects of GCA and SCA and generations and environments (crops and location) for both earliness and grain yield.

In the genetic control of earliness, we observed a predominance of additive effects, while in grain yield, dominance effects were observed.

The strain Goiano Precoce can be used as the genitor in breeding programs aiming to improve earliness, while strains RP1 and VC33 can be used to increase grain yield.

Gene complementation was observed for earliness in the crossings of Goiano Precoce with RP1, BRSMG Madrepérola and BRS Estilo strains, and grain yield between RP1 and Rosinha Precoce.

\section{Conflicts of interest}

The authors declare no conflict of interest.

\section{ACKNOWLEDGMENTS}

Research supported by the National Council of Technological and Scientific Development (CNPq) and the Foundation for the Support to Research of the State of Minas Gerais (FAPEMIG).

\section{REFERENCES}

Bernardo R and Bohn MO (2007). Plant breeding in times of change. Crop Sci. Soc. Am. 47: 2-3.

Bertan I, Carvalho FIF and Oliveira AC (2007). Genitor selection strategies in plant breeding programs. J. Crop Sci. Biotechnol. 10: 211-222.

Bertoldo JG, Coimbra JLM, Guidolin AF, Nodari RO, et al. (2009). Rendimento de grãos em feijão preto: o componente que mais interfere no valor fenotípico é o ambiente. Cienc. Rural 39: 1974-1982.

Buratto JS, Moda-Cirino V, Fonseca Júnior NS, Prete SCA, et al. (2007). Adaptabilidade e estabilidade produtiva em genótipos precoces de feijão no estado do Paraná. Sem. Cienc. Agr. 28: 373-380.

Bhullar GS, Gill KS and Khehra AS (1979). Combining ability analysis over F1-F5 generations in diallel crosses of bread wheat. Theor. Appl. Genet. 55: 77-80.

Carmo SLM, Santos JB, Hagiwara WE and Ferreira JL (2007). Avaliação do stay green em famílias segregantes de feijão (Phaseolus vulgaris L.). Ciênc. Agrotec. 31: 953-957.

Carneiro JES, Abreu AFB, Ramalho MAP, Júnior TJP, et al. (2012). BRSMG Madrepérola: common bean cultivar with late-darkening Carioca grain. Crop Breed. Appl. Biot. 12: 281-284.

Coimbra JLM, Bertoldo JG, Elias HT, Hemp S, et al. (2009). Mineração da interação genótipo x ambiente em Phaseolus vulgaris L. para o Estado de Santa Catarina. Ciênc. Rural 39: 355-363.

Cruz CD (2013). GENES - a software package for analysis in experimental statistics and quantitative genetics. Acta Sci. Agron. 35: 271-276.

Dalla Corte A (2005). Controle genético do caracter precocidade e de características morfológicas de sementes em genótipos de feijoeiro. Master's thesis, Universidade Estadual de Londrina, Londrina.

Geraldi IO and Miranda-Filho JB (1988). Adapted models for the analysis of combining ability of varieties in partial diallel crosses. Braz. J. Genet. 11: 419-430.

Griffing B (1956). Concept of general and specific combining ability in relation to diallell crossing systems. Aust. J. Biol. Sci. 9: 463-493.

Javaid A, Masood S and Minhas NM (2001). Analysis of combining ability in wheat (Triticum aestivum L.) using F2 generation. Pak. J. Biol. Sci. 4: 1303-1305.

Külzer SR (2012). Influência por estresse por frio em pré-colheita na qualidade tecnológica de feijão comum armazenado. Doctoral thesis, Universidade Federal do Paraná, Curitiba.

Genetics and Molecular Research 14 (3): 8219-8228 (2015)

CFUNPEC-RP www.funpecrp.com.br 
Masood MS and Kronstad WE (2000). Combining ability analysis over various generations in a diallel cross of bread wheat. Pak. J. Agric. Res. 16: 1-4.

Pereira DV, Sedyama T, Cruz, CD, Reis MS, et al. (2007). Adaptabilidade e estabilidade de genótipos de soja avaliados para resistência ao oídio. Ciênc. Rural 38: 1836-1842.

Pimentel AJB, Ribeiro G, Souza MA, Moura LM, et al. (2013). Comparação de métodos de seleção de genitores e populações segregantes aplicados ao melhoramento de trigo. Bragantia 72: 113-121.

Pixley KV and Bjarnason MS (1993). Combining ability for yield and protein quality among modified-endosperm opaque-2 tropical maize inbreds. Crop Sci. 33: 1229-1234.

Ribeiro ND, Antunes IF, Souza JF and Poersch N (2008). Adaptação e estabilidade de produção de cultivares e linhagenselite de feijão no Estado do Rio Grande do Sul. Ciênc. Rural 38: 2434-2440.

Tulmann Neto A and Sabino JC (1994). Indução e uso de mutante de hábito determinado e precoce em feijoeiro (Phaseolus vulgaris L.). Rev. Bras. Genet. 17: 425-430.

Viana JMS (2007). Heterosis and combining ability analyses from the partial diallel. Bragantia 66: 641-647. 